\title{
The Efforts of Eradicating Poverty as Reflected in Steinbeck's The Grapes of Wrath
}

\author{
Widya Hairunnisa ${ }^{1}$, Burhanuddin Arafah ${ }^{2}$, Herawaty Abbas ${ }^{3}$, Irmawati $^{4}$ \\ \{hairunnisawidya@gmail.com¹, burhan-arafah@unhas.ac.id², herawaty@unhas.ac.id ${ }^{3}$, \\ irmawatiimaarah@gmail.com $\left.{ }^{4}\right\}$ \\ Universitas Hasanuddin, Indonesia ${ }^{1,2,3,4}$
}

\begin{abstract}
The researchers aimed to describe the efforts of eradicating poverty as reflected in Steinbeck's The Grapes of Wrath. This research is combined some supporting theory to explain the concept of poverty clearly. Moreover, the researcher analyzed the portrait of poverty and the solutions through the novel by using Goldmann's genetic structuralism approach. The qualitative method is using by the researcher in order to collect and to analyze the data. The results of this research show the portrait of poverty causing by several conditions. Furthermore, in eradicating poverty through the novel, there are some efforts done by the characters and the governments which is new deal program.
\end{abstract}

Keywords: Eradicating Poverty, Genetic Structuralism approach, The Grapes of Wrath

\section{Introduction}

Literary work is a medium to express ideas, feelings and experiences of the author in regards to social reality that occurs at a particular time. Literary authors write using the depth of their imaginations, visions, assumptions, and intellects. They try to portray existing reality into a literary work. Literature as a branch of art has become a part of the human experience, both on the aspects of humans themselves who use literature for their life experiences and the aspects of its creators who appreciate their experiences into literary works. Wellek and Warren [1] stated that literature is a social creation expressed by the author using language as the media. Moreover, literature contains societal norms and it represents life and social reality. Thus, the reader can appreciate the reality and the human life problems that happen in society reflected in literary works [2].

In discussing social condition, it is necessary to use genetic structuralism theory by Goldmann. Goldmann argues in Milner [3] that there exists, not a direct structural homology between individual works of literature and the nature of social reality, but rather a set of structural homologies between them. On one hand, the individual work of literature and the world vision of the social class to which the writer belongs, and on the other, that world vision and the real social life of the times.

One of the social realities expressed by the author through literary works is poverty, in which this can be found in one of the greatest works written by Steinbeck, The Grapes of Wrath. This novel depicts the social life occurred during the Great Depression in America in the 1930s and it implies moral messages to the reader. The picture of reality illustrated in this case is poverty and how the characters in the novel tried to set themselves free from the shackles of 
poverty. In addition, the novel implies the efforts of eradicating poverty through some various ways that can provide moral values for readers and the world.

\section{Methodology}

\subsection{Design of the Study}

This research is conducted by using descriptive qualitative research. In using this method, the researchers explained the phenomena that occur in society by collecting the whole data in details, which in this case, are words, behaviors, attitudes and so forth. The researchers expressed and described the structure of the novel The Grapes of Wrath written by Steinbeck and the fundamental problems of life around the novel, as well as the social condition by using the genetic structuralism theory.

\subsection{The Subject of Research}

The Subject of this research is the novel written by Steinbeck, The Grapes of Wrath. The novel was published in 1939 by Penguin Books and it brought him win the Nobel Prize. This 455-page novel illustrates the problem of poverty faced by the characters in the novel and how these characters dealt with problems occurred during The Great Depression in America.

\subsection{Data Collection Procedures}

The researchers used library research method in collecting the data by reading the novel The Grapes of Wrath carefully, and also by reading theses, journals, and articles related to the novel. The researchers conducted note-taking technique in order to collect the data related to the social problems on the novel, including the words, dialogues, and sentences. Moreover, the researchers identified the data based on the object of study.

\subsection{Instruments}

In doing this research, the researchers used some instruments in collecting the data. They are as follows:

a. Brightly colored marker (stabilo); to highlight every important data in the novel and other printed sources related to the research.

b. Notebook; to write all the brainstormed ideas which were put by the writer during the process of collecting the data.

c. Pen and pencil; to write the main and the supporting idea into the small notebook.

d. Colorful sticky notes to mark every important point page in the novel.

e. 14-inch laptop; to arrange the presentation, to type, and to save all the important documents related to the research.

\subsection{Data Analysis Techniques}

After the process of collecting data, the researchers then analyzed the data. The researchers divided the data-analyzing process into three steps. Firstly, the researchers carefully read the 
novel The Grapes of Wrath as the object of this research. Secondly, the researchers collected several data, including the narrations, dialogues, and the monologue of the novel. Then, the researchers collected the important data. In this process, the researchers would use stabilo to mark all the data related to the portrait of poverty in the novel written by John Steinbeck, The Grapes of Wrath. Furthermore, the researchers marked the characters and the government's efforts to eradicate poverty. Lastly, the researchers wrote all the data into a notebook.

The researchers analyzed the data using Genetic Structuralism approach by Goldmann. This approach was used to describe the social condition of the poverty in the novel by looking aspects outside the literary work without separating it from the intrinsic elements. Finally, the researchers collected the data regarding the portrait of poverty and efforts to eradicate poverty.

\subsection{Procedure of the Research}

Firstly, the researchers read the novel repeatedly as the object of the research to understand the novel's deep meaning. Secondly, the researchers identified and highlighted the problems that are relevant to the research. Each data was marked by using stabilo. In this step, the researchers arranged all the data to classify the portrait of poverty and the efforts to eradicate poverty. Then, the researchers analyzed the data using genetic structuralism approach by Goldmann to complete the research. Lastly, the researchers described all the important data related to poverty and efforts in eradicating poverty in the form of a research report.

\section{Finding and Discussion}

\subsection{Finding}

There are several causes of poverty. OECD [4] describes that there are some major points causes of poverty. The first is malnutrition, a condition of human body facing nutrition disorder for growth. When someone is poor, they do not have enough money to buy the proper food fit to the balanced nutrition. The second is unemployment, a number of people who do not have a job yet. Unemployed people cannot earn money to fulfill their basic needs because they cannot earn money. Furthermore, the higher the unemployment rate in a country, the higher the poverty rate becomes. The third is environmental degradation, including degradation of forests, soils, and water, can causes poverty directly. Overpopulation and land-exploitation can affect the lack of food, clean water, and materials for shelter-building. Furthermore, this exploitation has effects on natural disasters, such as flood, global warming, and erosion.

Steinbeck reflected the explanation above into his works entitled The Grapes of Wrath. There are two major causes of poverty described in the novel, which are Great Depression and Dust Bowl. Below, the specific explanations clearly explained:

\subsubsection{Great Depression}

Great Depression is a traumatic experience to all Americans. It was happened during 19291940. Himmelberg [5] explains that the depression brought suffering and hardship to all Americans. They were struggling during the time with all fears and starvations. Furthermore, all banks faced bankruptcy. Farmers' land confiscated because they were unable to pay debts to 
banks. Therefore, many people lost their jobs, their homes, and also their land. This phenomenon is portrayed in quotation below:

Data 1: in the barns, the people sat huddled together; and the terror came over them, and their faces were gray with terror. The children cried with hunger, and there was no food [6].

The quotation above describes that the effects of Great Depression made people lose their homes. In addition, they lived together in barns and felt hunger because there were no jobs for everyone. Therefore, they could not get enough money to buy some foods [3].

Steinbeck also portrayed the farmers who lose their land as the effect of Great Depression. They were forced to leave their land without money and home because they did not pay their debts on bank. This situation is described through the dialogue below:

Data 2: And now the owner men grew angry. You'll have to go. But it's ours, the tenant men cried. We-No. The bank, the monster owns it. You'll have to go...We're sorry, said the owner men. The bank, the fifty-thousand-acre owner can't be responsible. You're on land that isn't yours [6].

The dialogue above explained how bank treated the farmers harshly. The bank forced the farmers to leave their land. They did not care about the farmers' fate who only live on agricultural produce. Furthermore, the farmers were told to leave their land which did not longer belong to them.

The other effect of Great Depression is that it made people in Oklahoma migrated into the hope land, which is California, to get a better life. Along their journey, they needed gasoline to keep them moving. However, they did not have money and they tried to exchange anything with gasoline. This condition revealed through this quotation below:

Data 3: It ain't that I'm tryin' to git trade outa rich folks," the fat man went on. "I'm jus' tryin' to git trade. Why, the folk that stops here begs gasoline an' they trades for gasoline. I could show you in my back room the stuff they'll trade for gas an' oil: beds an' baby buggies an' pots an' pans. One family traded a doll their kid had for a gallon. An' what'm I gonna do with the stuff, open a junk shop? Why, one fella wanted to gimme his shoes for a gallon. An' if I was that kinda fella I bet I could git- " He glanced at Ma and stopped [6].

The quotation above depicts many people who lose their home became migrants and set their long journey to another land where they could find a job. Many of the migrants faced many problems through their journey. One of the problems was that they ran out of gasoline and water. Thus, the migrants exchanged their stuffs, even the useless stuffs, to get gasoline and water because they had no money and job.

\subsubsection{Dust Bowl}

Dust bowl is an environmental degradation that destroyed the Midwest during 1930s. This storm brought pain for all American. The huge dust storm devastated crops and all properties in American communities. The dust storm affected economic problems during that time and 
leaving people in homeless and hungry condition [7]. This condition depicted through The Grapes of Wrath. As we can see through the quotation below:

Data 4: The squatting tenant men nodded and wondered and drew figures in the dust, and yes, they knew, God knows. If the dust only wouldn't fly. If the top would only stay on the soil, it might not be so bad. The owner men went on leading to their point: You know the land's getting poorer. You know what cotton does to the land; robs it, sucks all the blood out of it. The squatters nodded - they knew, God knew. If they could only rotate the crops, they might pump blood back into the land... Yes, he can do that until his crops fail one day and he has to borrow money from the bank [6].

From the narration above, Steinbeck reflected how terrible the dust storm that hit America, particularly in the Oklahoma. This storm made the soils dry. Therefore, the lands got infertile over time. The farmers could not crop the corn that they were planned.

Most people in Oklahoma were farmers and their only mean of life was crop-producing. The storm that happened in Oklahoma did not only affect the land, but it also made people facing hunger. There were no foods for family, even for the children. This situation made them trapped in poverty. As revealed by the narration below:

Data 5: The squatting men looked down again. What do you want us to do? We can't take less share of the crop-we're half-starved now. The kids are hungry all the time. We got no clothes, torn an' ragged. If all the neighbors weren't the same, we'd be ashamed to go to meeting [6].

Data 6: Oh! They talked pretty about it. You know what kinda years we been havin'. Dustcomin' up an' spoilin' ever'thing so a man didn't get enough crop to plug up an ant's ass.An' ever'body got bills at the grocery. You know how it is. Well, the folks that ownsthe lan' says, 'We can't afford to keep no tenants.' An' they says, 'The share a tenantgets is jus' the margin a profit we can't afford to lose.' An' they says, 'If we put all ourlan' in one piece we can jus' hardly make her pay.' So they tractored all the tenants off athe lan' [6].

Based on the narrations above, the storm made all farmers in Oklahoma must leave their land because they could not afford to pay the tax and there nothing could be expected from the land that was hit by dust. Moreover, the harvest cannot fulfill family basic needs and the disaster brought famine. Moreover, they did not have proper clothes to wear.

\subsection{Discussion}

Poverty is a condition that is never expected by almost every human being. Poverty is a condition where people are unable to fulfill their basic needs such as food, clothing, shelter, education, and health care. Furthermore, this condition makes people incapable, powerless, and even tend to feel hopeless to deal with the situation. The researchers realize that poverty is a crucial problem that affects human daily lives. Therefore, it is important to understand ways to eradicate this problem. 


\subsubsection{New Deal Policy}

Roosevelt as the elected president 32nd president of America released a new policy which he called The New Deal Program, in order to against Great Depression. According to Fishback [2], The New Deal program includes the provision of funds for roads, reclamation and irrigation, flood control and navigation improvement, post office building and federal building, mortgage loans and emergency plant and feed loans for farmers, agricultural trials, counseling, and education [7].

\subsubsection{Government Camp}

One aspect of The New Deal program reflected in the novel is in regard to shelter-provision for immigrants. Government provided a camp named Weed patch with tents and adequate sanitation for the immigrants to make them comfort. The immigrants can stay there for free but they should maintain the camp cleanliness. This situation described by the following dialogue below:

Data 7: Well, the camp site costs a dollar a week, but you can work it out, carrying garbage, keeping the camp clean—stuff like that [6].

From the dialogue above, the camp security explains the camp to the immigrants. He talked about the cost of the camp. Furthermore, he explained that the immigrants can shelter in the camp for free by carrying the garbage and keeping the camp clean. This policy relieved the suffering of immigrants who did not have a house for shelter.

The government camp, which is Weed-patch not only provides shelter but also offers good sanitation and water to the migrants. This good sanitation has a huge impact in order to alleviate poverty. Therefore, the migrants could stay comfortable. As we can see from the narration below:

Data 8: Over by Weedpatch. Got nice toilets an' baths, an' you kin wash clothes in a tub, an' they's water right handy, good drinkin' water; an' nights the folks play music an' Sat'dy night they give a dance. Oh, you never seen anything so nice. Got a place for kids to play, an' them toilets with paper. Pull down a little jigger an' the water comes right in the toilet, an' they ain't no cops let to come look in your tent any time they want, an' the fella runs the camp is so polite, comes a-visitin' an' talks an' ain't high an' mighty [6].

Based on the narration above, the Weed patch camp was one of the best places for migrants. Firstly, they could enjoy the water as long as they wanted. Secondly, the camp provided proper toilet with toilet paper inside. It also provided a tub to wash clothing. The most important camp facility was the clean water to drink.

The migrants felt happy for the camp, especially for the water that was provided by the camp. They can enjoy the water for their daily activities. The quotation below makes us realize how important the water was for the migrants:

Data 9: She blushed under Ma's gaze. "You had a bath", Ma said. Rose of Sharon spoke huskily. "I was in there when a lady come in an' done it. Know what you do? You get in a little stall-like, an' you turn handles, an' water comes a-floodin' down 
on you — hot water or col' water, jus' like you want it—an' I done it!" "I'm a-goin' to myself”, Ma cried. 'Jus' soon as I get finish' here. You show me how [6].

Based on the dialogue above, Rose of Sharon was happy when she could shower with clean water. Furthermore, she could also use as much water as she wanted. The clean water and good sanitation were very important because people could clean their body and utilize water for domestic needs. Clean water and good sanitation could lower various diseases people may have.

Through the novel, the government camp and good sanitation were depicted as the appropriate strategy in eradicating poverty. The quality of water and sanitation give a hugely affect health and environment. Thus, people should gain good sanitation in their daily lives.

\subsubsection{Credit for Farmers}

Another policy revealed in the novel is loans for farmers. The dust bowl destroyed the entire farmer's land. Thus, the farmers could not harvest their crops during this environmental degradation. This condition made the farmers get poorer. They also lost their land because they cannot pay debts to the banks. In dealing with this situation, the government provides loan for farmers. As described by the quotation below:

Data 10: Did you ever hear of the Farmers' Association?" "Why, sure". "Well, I belong to it. "And by the way,' he says, 'you going to need the usual amount for a crop loan next year? [6].

From the quotation above, it can be known that the farmer association was the group of small farmers in California. It allowed the members to loan from a bank. This policy can make small farmers can survive from Great Depression and the dust bowl that hit Americans which were depicted in the novel.

\subsubsection{Food}

Food is one of the important solutions in eradicating poverty. As the researchers already explained in the finding, during the dust bowl, all farmers in Oklahoma deal with crop failure. Therefore, they cannot afford to produce food for people, even for their family. The famine was happened in the entire city. The farmers anticipated this problem by feeding each other. This situation described by the following dialogue below:

Data 11: When the smell of the biscuits struck the air both of the men inhaled deeply. The younger said, "Kee-rist!" softly.

Now the older man said to Tom, "Had your breakfast?"

"Well, no, I ain't. But my folks are over there. They ain't up. Need the sleep".

"Well, set down with us, then. We got plenty-thank God! [6].

Based on the conversation above, the characters asked Tom to join breakfast with them. They asked him because they had a lot of food. Also, they realized that Tom already arrived at the camp but he did not have food yet. Therefore, they invited Tom to have breakfast with them. This is a right way to minimize hunger between the migrants. 
The government realized that food is one of the crucial needs for everyone. People cannot do their daily activities without eating because they did not have energy. Therefore, the government also provided credit to the migrants to get enough food. This situation revealed by the quotation below:

Data 12: Now you hol' up your head," Jessie said. "That ain't no crime. You jes' waltz right over $t^{\prime}$ the Weedpatch store an' git you some groceries. The camp got twenty dollars'credit there. You git yourself fi' dollars' worth. An' you kin pay it back to the Central Committee when you git work. Mis' Joyce, you knowed that," she said sternly. "How come you let your girl's git hungry? [6].

According to the above quotation, the Weed-patch camp had a food store. This camp allowed the migrants to get a credit for food even though they did not have any job yet. However, they could pay the credits back in the Central committee when they have money and get a job. The committee really paid their attention, especially toward the children. They did not want to see any child in the camp faced a starvation.

\section{Conclusion}

After analyzing the novel of The Grapes of Wrath written by Steinbeck uses the genetic structuralism approach and the concept of poverty, the researchers concluded that there are two main problems caused poverty depicted in the novel. They were the Great Depression and the environmental degradation which was the dust bowl. Finally, the researchers give the solution in eradicating poverty through the novel that is The New Deal Program; this program includes government camp named Weed patch Camp which is inhabited by the migrants, adequate sanitation and water in Weed patch camp, credits for farmers, and adequate food which is one of the crucial solutions to avoid hunger faced by the migrants.

\section{Acknowledgement}

I gratefully acknowledge that the research was supported by my beloved parents $\mathrm{Mr}$. Haruddin and Mrs. Maisarah. Thank you for their pray, support, and unconditional love.

\section{References}

[1] R. Wellek and A. Warren, Theory of literature. Harcourt, Brace \& World New York, 1956.

[2] P. V Fishback and J. J. Wallis, "What was new about the New Deal?," National Bureau of Economic Research, 2012.

[3] A. Milner, John Milton and the English Revolution: A Study in the Sociology of Literature. Macmillan International Higher Education, 1981.

[4] Organisation for Economic Cooperation and Development, "Competition and Poverty Reduction." Global Forum on Competition Printing, Paris, 2013.

[5] R. F. Himmelberg, The Great Depression and the New Deal. Greenwood, 2001.

[6] J. Steinbeck, "The Grapes of Wrath.” Viking Penguin, New York, 1939.

[7] R. A. Reis, The Dust Bowl. Infobase Publishing, 2008. 